\title{
Growth, exclusion and vulnerability:
}

\section{evaluation of the socio-spatial transformation of post-apartheid Pretoria-Tshwane (South Africa)}

Crecimiento, exclusión y vulnerabilidad: evaluación de la transformación socio-espacial en Pretoria-Tshwane (Sudáfrica) post-apartheid

\author{
Andre Horn \\ hornac@unisa.ac.za \\ Department of Geography \\ University of South Africa (South Africa)
}

\begin{abstract}
Apartheid left South African city regions with two major challenges: social integration at a city level and spatial integration at a regional level. The task to finds solutions to these problems was left to municipalities, the lowest level of the three trier government system introduced after 1994. This article critically evaluates the success of the post-apartheid municipal government of PretoriaTshwane to address the said challenges in the reorganization of the city region over a 25-year period. The paper starts with a reconstruction of the apartheid city to display its socio-spatial contrasts and to define the challenge of integration and compaction. The investigation is based on literature, census information and observation. The main finding is that the progress made with the integration of the city at both scales is being neutralized by demographic trends, choice of association, urban sprawl, uncertain management, the scale of aspirations, unrealistic expectations and, most of all, municipal incapacity. The failure of the local government of Pretoria-Tshwane to achieve the said goals points to the inefficiency of the current approach that obligates municipalities with the complete task to rectify the dichotomies of the apartheid city
\end{abstract}


system within their regions. It is advocated that additional governmental entities be implemented to support local governments with the planning and re-development of post-apartheid cityregions.

Key words: Pretoria-Tshwane; local government; spatial integration; regional development; supportive need.

\section{Resumen}

El apartheid produjo dos grandes desafíos en las regiones urbanas de Sudáfrica: la integración social a nivel de ciudad y la integración espacial a nivel regional. La tarea de encontrar soluciones a estos problemas se dejó en manos de los municipios, el nivel más bajo del sistema de gobierno de tres niveles introducido después de 1994. Este artículo evalúa críticamente el éxito del gobierno municipal de Pretoria-Tshwane post-apartheid a la hora de abordar estos desafíos de reorganización de la región urbana durante un período de 25 años. El artículo comienza con una reconstrucción de la ciudad del apartheid, mostrando sus contrastes socioespaciales y definiendo los desafíos de la integración y la compactación. La investigación se basa en el uso de literatura, información censal y observación. El principal resultado es que los avances en la integración de la ciudad en las dos escalas están siendo neutralizados por las tendencias demográficas, la libertad de asociación, la expansión urbana, una gestión incierta, la escala de aspiraciones, expectativas poco realistas y, sobre todo, la incapacidad municipal. El fracaso del gobierno local de Pretoria-Tshwane para alcanzar estos objetivos se explica por la ineficacia del enfoque actual, que obliga a los municipios a rectificar las dicotomías del sistema de ciudades del apartheid dentro de sus regiones. Se aconseja implementar entidades gubernamentales adicionales para apoyar a los gobiernos locales en la planificación y la reurbanización de las ciudades-regiones post-apartheid.

Palabras clave: Pretoria-Tshwane; Gobierno local; integración espacial; desarrollo regional; necesidad de apoyo.

\section{Introduction}

In early 1990 the typical South African city, influenced by an era of racial oppression and feeble attempts to morally justify it, was characterised by managerial, social and spatial fragmentation (Baffi et. al, 2018). The racial separation and discrimination of apartheid was replaced in 1994 by a democratically elected government with representation at national, provincial and local 
governmental levels. At the level of local government the country is divided into wall-to-wall municipalities that each includes cities and/or towns and surrounding areas. These municipalities are tasked with the planning, development and management of often large areas and at the same time carry the burden to undo apartheid's spiderweb of territorial, racial and social division through social and spatial urban restructuring (Harrison \& Todes, 2013; Parnell \& Crankshaw, 2013). The new combined planning, development and integration approach at the municipal level is in contrast with the plural structure of municipal-, town- and regional councils supported by other governmental entities that, in a co-ordinated fashion, performed the duties of planning, construction and maintenance during apartheid times.

In this article the city of Pretoria-Tshwane is used as a case study to evaluate the success of its local government's aim to undo the socio-spatial disparities of the past and specifically to link the displaced, immobile, and vulnerable population to the benefit of the city (CDE, 1998a; South African Cities Network, 2014).

At the end of the apartheid era Pretoria-Tshwane faced two major socio-spatial challenges. Municipal consolidation implied the integration of the Pretoria core area with an arc of poor black African dormitory towns established by the apartheid government (Perlman, 1982). This twin-city structure explains the use of name Pretoria-Tshwane in this article for the two main urban components of the region that became the City of Tshwane Metroplitan Municipality (CTMM) in 2011. Secondly, apartheid divided the South African population into different racial groups ${ }^{1}$ with different social and economic standings and settled and re-settled these groups in segregated parts of the core city. Addressing the spatially expressed social disparities in the city became the second challenge to the new post-apartheid local government. Investigating progress with the integration of the twin-city and eradicating the socio-spatial duality in the city represents the aim of this article. The structure and functioning of local government in South Africa is increasingly been questioned (Maharaj, 2020) but this article goes further than criticising the theoretical spatial conceptualisation of Pretoria-Tshwane (Serfontein \& Oranje, 2007; Horn, 2009) by challenging

1 Four official racial groups were declared: black Africans, coloureds (an ethnic mix of hunter-gatherers collectively referred to as bushman, herders and planters such as the Khoikhoi and Griqua, imported slaves from areas such as Malaysia, and the produce of the sexual interaction of european settlers and people of colour), Indians (the descendants of slaves imported from India during the 19th Century to work in the British colony of Natal), and whites (people considered to have 'pure' European anchestry). The status of Asian people (other than Indians) were uncertain for a period of time but eventually they became members of the white race as to avoid confusion and further complication of an already convoluted situation. In broad, the black African race group represented about $80 \%$ of the population of the country at the time of writing, whites about $10 \%$ and coloureds and Indians $5 \%$. Collectively the three non-white groups are referred to as blacks in this article. 
the capacity of the local government to manage its task of integrated planning and development, and by proposing a radical change to the structure of development management at the local level.

The remainder of the article is presented in three parts. The first deals with the formation of apartheid Pretoria-Tshwane and the definition of the challenge to integrate the city at the two scales outlined above. The next part comprises the critical evaluation of the post-apartheid integration of the twin-city and reshaping of racially divided city. The article concludes with a reflection on the investigation and hypothesis.

\section{Site and situation}

Rims of paper have been dedicated to articles, books and book chapters about the origins and growth of the apartheid city - see for example a collection of contributions entitled Homes ApartSouth Africa's Segregated Cities, edited by Anthony Lemon (1991) and Maylam's summation of literature on the topic (Maylam, 1995).

A combination of racial, political, economical and territorial domination became the grounding principle of South African society and defined the social and spatial structure of South African cities (Maharaj, 2020). Since the mid-17th century, the start of the colonial period in South Africa, cities typically developed around a commercial and administrative centre with distinguishable areas of residence for the white elite and lower-class whites, and an undefined arrangement of dwellings occupied by the other races (Christopher, 1983). Pretoria was established in 1855 and soon became the capital city of the Transvaal colony. The Transvaal was an area that today lies between the Vaal river in the south, the Limpopo river in the north, and with Mozabique to the east and Botswana to the west. Following the discovery of gold in 1886 Johannesburg was established about $60 \mathrm{~km}$ south of Pretoria. When the four white controlled colonies merged in 1910 Pretoria became the administrative capital of South Africa. Pretoria displayed a localised variation of the typical colonial city. It encompassed a central business district, an elitist income area to the east and south-east, poor-white residences closer to the city centre, an Asiatic bazaar to the west and a circular zone of African locations and mixed-race residential areas (Olivier \& Hattingh, 1985).

From the 1920's the land-use patterns in South African cities became more formally organised with clear divisions between administrative and commercial centres, industry and residential areas. Locations were demarcated for blacks and a process of re-location of blacks from various 
parts of a city to the declared locations commenced. Davies (1981) captured the most common strands of South African cities before 1950 and modelled it as the 'segregated' city. The principle of racial differentiation became entrenched in 1950 by the Population Registration Act that determined the classification of the residents of the country into four artificially defined 'races' as described above. Residentially, the four defined racial groups were restricted to racially segregated residential areas in cities and towns by the Group Areas Act of 1950. Mixed race freehold areas were demolished. Locations were established for each of the African, coloured and Indian races on the outskirts of cities with 'buffer zones' in the form of industries and/or green belts between the white and black residential areas (Davies, 1981). In the case of Pretoria the growth of affluent white residential areas continued to the east and south east of the central business district while poorer white areas were established north and north east of the central city. An African township, Atteridegeville, was proclaimed to the west of the city with an Indian residential area, Laudium, south of this township. In the north east a coloured township, Eersterust, was established and another African township, Mamelodi, was developed east of Eersterust. An industrial buffer zone, Waltloo, was established between the townships in the north east and the white city, and another (Pretoria West industrial) between the western townships and the city centre. Hence, by 1950 Pretoria closely resembled the model of the apartheid city drafted by (Olivier \& Hattingh, 1985). The white controlled region of Pretoria exapanded so fast that it was divided into three municipalities, Pretoria in the centre, Verwoerdburg to the south and Akasia to the north of Pretoria proper (Figure 1).

Despite measures that controlled the influx of Africans to cities in the country, their absolute numbers in many cities surpassed that of whites, even during the early stages of apartheid (Smit \& Booysen, 1981). In order to curb the influx of Africans to the cities a scheme of separate and autonomous territories for the various African ethnic groups was devised. Part of the original plan was to develop self-sustaining towns and cities in these 'homelands' but it was undermined by a dominant conservative faction in the government of the day. Instead, large scale industrial zones were established between the homelands and the white-controlled cities. Thus, the homeland border-towns were nothing more than dormitory towns for cheap labour. This strategy served two purposes: The economic benefit of the growing white-owned industrial sphere, and the confinement of Africans by further regulating their access to the city (Morris, 1994).

In the vicinity of Pretoria a Tshwane homeland was established north west of Pretoria. Apart from Hammanskraal (an existing trade centre) and Winterveld (an existing African agricultural scheme) an arc of homeland border towns - Temba, Mabopane and GaRankuwa - were established in 
the Tshwana homeland with Rosslyn functioning as an industrial buffer between the white controlled city and the homeland (Smit, 1969). The situation became even more complicated in the late-1970s when the Tshwana homeland became an 'independent' state (Horn, 1998). The government of the new state embraced the principle of ethnic states and expatriated non-Tshwane from the state. This forced the South African government to establish a new town, Soshanguve, on the South African side of the border (Horn, Hattingh \& Vermaak, 1992).

Figure 1. Orientation: Pretoria-Tshwane

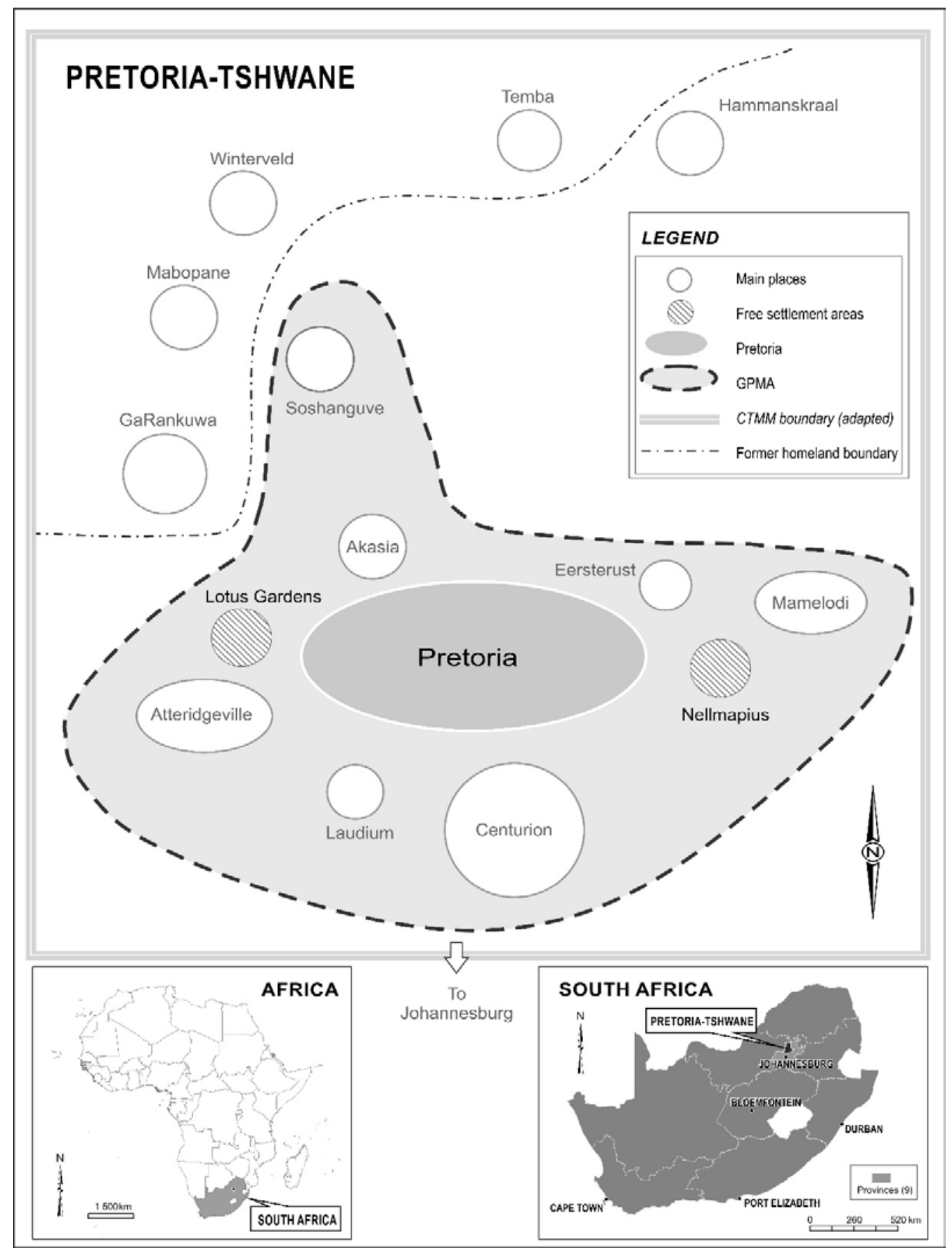

Source: the author, based on historical information 
At the end of apartheid the Pretoria functional region included several local governments with different statures. Hattingh and Horn (1991) referred to this conglomerate as a 'multiple' city system. According to the CDE (1998b) this multiple city system was a dysfunctional city characterised by racial and social inequalities, spatially incompatible urban realms, and a confusing system of local government.

After the re-unification of the country in 1994, the transition to democracy and the election of a black majority government the first step in the consolidation of the Pretoria city system was the amalgamation of Akasia, Verwoerdburg (re-named Centurion) and Pretoria (including Atteridgeville, Eersterust, Laudium, Lotus Gardens, Mamelodi and Nellmapius) to become the Greater Pretoria Metropolitan Area (GPMA) in 1995.

The period from 1995 to 2001 was a transition phase during which a new form of local government and its role was developed. Alongside the establishment of country-wide municipalities the concepts of 'developmental local government' (the new form of local government), 'integrated development planning' (its prescribed approach), and 'spatial transformation' (the expected outcome) became entrenched (Todes, 2006). The 'spatial transformation' of cities implied the 'social integration' of cities, the 'connection' of disconnected urban areas and the 'compaction' of sprawling cities (Harrison \& Todes, 2013). The core objective of the new approach was to balance growth with inclusion through planning and development (Lemon, 2002; Turok \& Watson, 2002; Harrison et. al, 2008). A series of strategies, frameworks and planning instruments were introduced to guide and assist local governments in their tasks (Todes 2006; Turok \& Parnell, 2009; Maharaj, 2020).

The City of Tshwane Metropolitan Municipality (CTMM), replaced the GPMA in 2001 and its region of responsibility was demarcated. The area of the new municipality closely resembled Pretoria's function region as defined by CDE (1998a). In 2011 the population in the area numbered 2.9 million people ${ }^{2}$ and is estimated to increase to 3.5 million people in 2021 (Udjo \& van Aardt, 2017). It became the task of the CTMM government to orchestrate the 'spatial transformation' of the new city region.

2 Data retrieved from StatsSA (http://www.statssa.gov/?page_id=1021\&id=city-of-tshwane-municipality [accessed April 2020]). 


\section{Evaluation}

The evaluation of the spatial transformation of Pretoria-Tshwane is presented in two parts. The objective to create a compact city is discussed first, followed by an evaluation of the objective to improve the racial and economic integration of residential areas in the city.

\subsection{Towards a consolidated city}

Urban consolidation through integration, compaction, densification and infilling was the set approach during the early phases of post-apartheid urban transformation (South Africa, 2004; Serfontein \& Oranje, 2007). The motivation for this objective was the reconnection of the 'discarded' people on the urban periphery with the main city and its advantages (CDE, 1998a; South African Cities Network, 2016), and to reduce the cost of development and service provision (van Niekerk, 2018).

Figure 2 shows that Pretoria-Tshwane, after its amalgamation, was an extreme example of a malformed, twin-city. It displayed two sections that were only linked at a single point giving the city a 'gaping mouth' resembling a 'pac-man' profile. In 1996, the north western section accommodated $47 \%$ of the city's population and the southerly central part $4 \%{ }^{3}$ The remaining parts of the region accounted for $4 \%$ of the population. This confirmed the homeland border towns as being located on the wrong side of 'the great divide' (Serfontein, 2006). Since the north-south axis of the metropole measures approximately $80 \mathrm{~km}$, it confronted the post-apartheid local government with the challenge of socially and economically developing the neglected former homeland border towns, connecting this region with the main city through an extended and upgraded transport system, development corridors and the residential, economic, and industrial development of the 'gaping mouth' of the twin-city.

In terms of transport a network of railways established during the apartheid era still exist. The main lines link Mamelodi and Eersterust to Central, Atteridgeville and Central, Centurion and Central, a line linking GaRankuwa and Pretoria North (located between Akasia and Montana), a line linking Temba and Hammanskraal with Pretoria North, and finally a railway line linking Pretoria North with Central. The improvement and maintanance of this railway network was nevertheless inadequate and it no longer has the capacity to meet the requirements of thousands of commuters from the northern and north western urban periphery. Due to systems failure, a trip

3 Author's calculation from the 1996 national population census conducted by StatsSA (https://apps.statssa.gov.za/Census01/Census96/HTML/default.htm). 
of 45 minutes from the north west to Central sometimes takes over two hours. Crime and overcrowding are characteristics of the railway network and therefore many commuters prefer other modes of transport such as busses and combi-taxi's to the industrial zones, suburbs and the city centre.

Figure 2. The twin-city of Pretoria-Tshwane

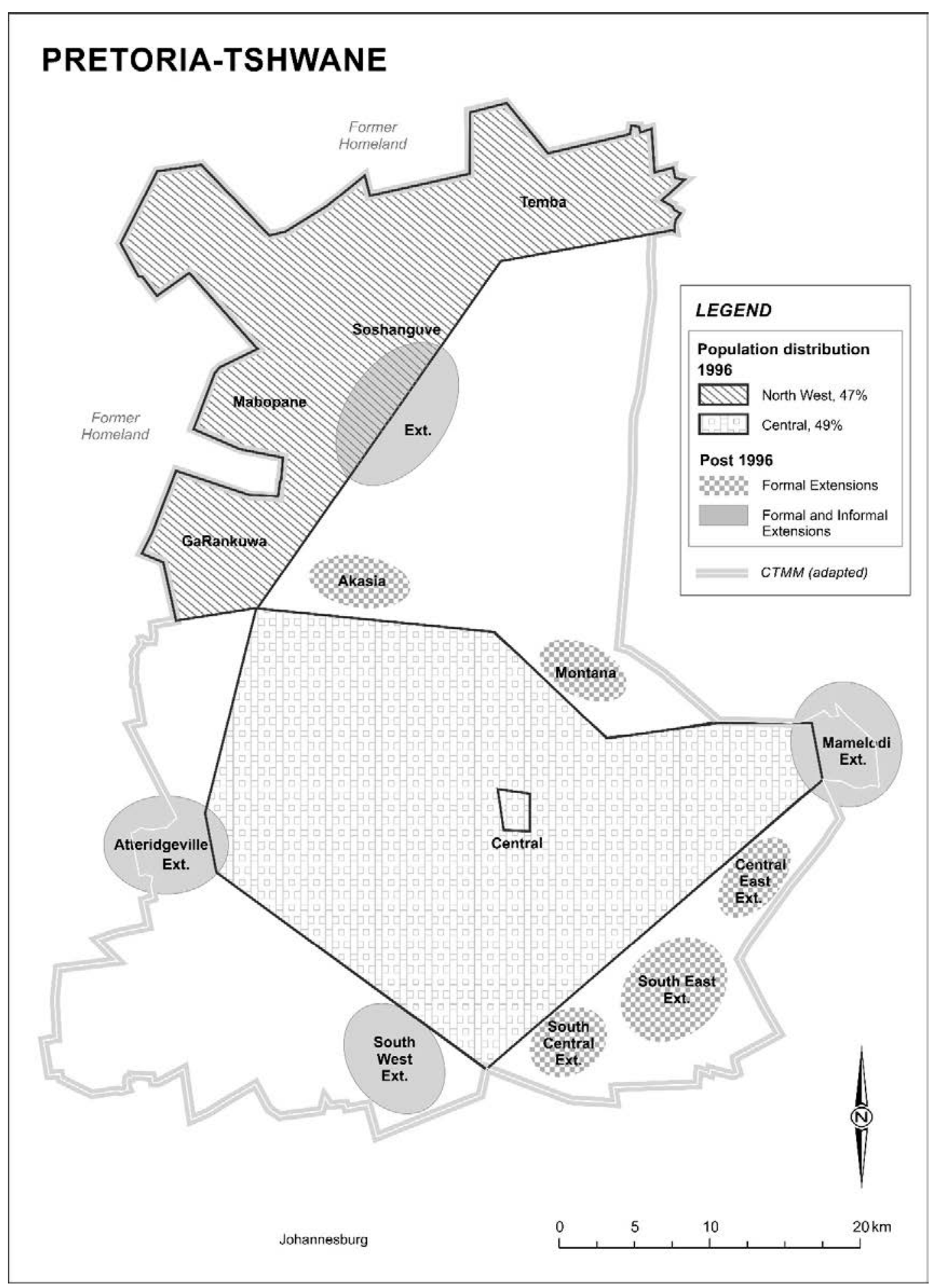

Source: the author, based on observation and interpretation 
On the other hand, the road system, used by private vehicles, combi-taxis and busses has been upgraded to a considerable extent. National Road no. 1 (the main highway between Cape Town in the south and the border with Zimbabwe) is used as a link between Temba/Hammanskraal and the eastern- and southern parts of the city on its way to Johannesburg. A four-lane highway was constructed between Central and Mabopane. However, the road networks between the west (including Atteridgeville) and Central, carries high traffic volumes, and the road link between Eersterust and Mamelodi in the east and Central is in a poor condition. Lastly, the envisioned transport and development corridor between Mabopane and Centurion has after almost two decades not materialised.

In their contribution to the book Homes Apart-South Africa's Segregated Cities, Hattingh and Horn (1991) provided a detailed description of the daily rhythm of an African person living on the distant parts of the urban periphery. It was indicated that such a person left at about 04:00 and, after a day's work, arrived at home after 19:00. Recent personal communication with several commuters, made it is clear that the improvement made to the transport system has been countered by population growth due to increased influx to the periphery of the city.

In terms of industrial development Pretoria-Tshwane is growing fast. Over the past decade the city has become a main production and assembly node of the motor industry. However, this growth is confined to the existing industrial zone between the Eersterust-Mamelodi complex, and the apartheid buffer zone between Akasia and GaRankuwa. However, the black townships in the vicinity of these industrial areas are still negated.

Figure 2 also indicates that, after 1996, planned extension with formal housing occurred in the south east of the main city, extending the original growth axis of the city in that direction, as well as at Akasia and Montana in the northern periphery of the core city. Although the development of an urban node in the region, indicated as South on Figure 2, includes both formal and informal housing, it was a planned extension of the city, rather than sprawl. The same applies to the formal/informal extension of Soshanguve in the northwest. However, the extensions of the African townships of Atteridgeville and Mamelodi represent uncontrolled sprawl, occupied largely by unemployed and vulnerable citizens.

It is clear that the attempt by Pretoria-Tshwane's post-apartheid local authority to create a compact city failed at the large scale. The reasons are a combination of general (national) and specific (local) dynamics. At a national scale, the growth of poor, unemployed urban populations have overwhelmed local authorities (South African Cities Network, 2014). This is also the case in 
Pretoria-Tshwane. The result is a focus on low-cost housing projects that countered the ability to obtain land for development and lure private sector investments to strategic areas in the city (Todes, 2006). This problematic situation is further exacerbated by Pretoria-Tshwane's obligation to abide to the theoretical construct of the provincial government of Gauteng to contain urban development within a radius of $25 \mathrm{~km}$ around city centres, a guideline that excluded the largest part of the city's homeland border region (Horn, 2009), and by the economic gravity of Johannesburg, which draws professional labour and private investment to the south, leaving the northern periphery behind (Serfontein, 2006; Sefontein and Oranje, 2007). Consequently, the vulnerable population on the periphery of the city remains marginalised and unsatisfied with their quality of life (South African Cities Network, 2016; Peberdy et. al, 2017; Koech et. al, 2019).

\subsection{Race and income}

The distribution of race and income in South African cities are intertwined and is discussed with reference to Figure 3 (racial and broad household income distributions) and Table 1, that presents a classification of race and income distributions. Presentations of race and income distributions in South African cities are usually indicated per residential areas (more than 500 in the case of Pretoria-Tshwane), an ever-changing number of election, or large development regions. The result is that these expressions are either too small to identify general trends or so large in scale that finer nuances are not demonstrated. For the purpose of this study the author divided the study area into 26 regions that each demonstrate similar characteristics at a medium scale and allows meaningful discussion (Figure 3).

The aim of the Groups Areas Act of 1950 was to segregate the residential areas of the four racial groups. This was to an extent a surreal arrangement as the races mixed in the work situation and public open areas while only limited and regulated mixing were allowed in public facilities such as shops and recreation. Apartheid further implied that blacks were required to return to their own residential areas after their daily activities until the next day, as determined by curfew regulations. Only black workers with special permits were allowed to overnight in white group areas. They were usually accommodated on the premises of industries and other retail and administrative centres. Domestic servants/workers could also stay on premises of households, typically in backyard rooms with only basic facilities. The result was that up to $20 \%$ of the population in white group areas were black (Christopher, 2001). 
During the early stages of the post-apartheid desegregation Prinsloo and Cloete (2002) identified the following trends:

1. The flow of young blacks to inner city flats

2. The increased residential mobility of young black families

3. A preference of new smaller houses in the region of the former townships.

Subsequent trends and patterns of racial desegregation in Pretoria Tshwane were investigated and reported by Horn (2002; 2005) and Hamann and Horn (2014; 2015). Deductions by the author from the data provided by StatsSA referenced in footnote 2 indicate that in 2011 black residents still dominated the periphery of the original Pretoria part of the city, apart from the south east that is a higher income growth area (Figure 3). The region North West was originally proclaimed as a high-income white group area, but this was one of the first residential areas to desegregate with the development of The Orchards, a middle income neigbourhood that is popular among young Africans, partly because of its proximity to the homeland border towns (Prinsloo and Cloete, 2002; Horn and Ngcobo, 2003). The presence of black majorities in Central West and Moot East are also not surprising because these regions include the original townships of Atteridgeville, Eersterust and Mamelodi as well as Lotus Gardens and Nellmapius that were established at the end of apartheid for mixed-race occupation. Specific attention should be given to the city centre (Central) because here a black majority has replaced a white majority between the years 1990 and 2011 (Donaldson et. al, 2013). Just east of Central is a region with a diversity of residences that range from expensive houses, flats for young workers, old age homes, and student residences. In 1990, this area was almost exclusively occupied by whites but now has a dominant black (particularly African) population. In terms of population transformation this is one of the most dynamic regions in the city (Figure 4).

In terms of the changing population distribution, four general observations stand out. Firstly, the original large-scale divide in the city has not changed much in the past three decades. In fact, the overwhelming influx of poor blacks, has accentuated the failure of the local government to integrate these new migrants into a compact city. Secondly, old apartheid patterns of predominantly white and black parts of the city prevail. Thirdly, the continuing growth of a mainly white population in the south east has become an entrenched phenomenon. Finally, the change of the racial profile of the population in Central and Central East is significant. Figure 3 also indicates that five white concentrations are evident in parts of the regions North West, North Central, Moot Central, South West and South East Extension. 
Figure 3. Race-economic duality in Pretoria-Tshwane

\section{PRETORIA-TSHWANE}

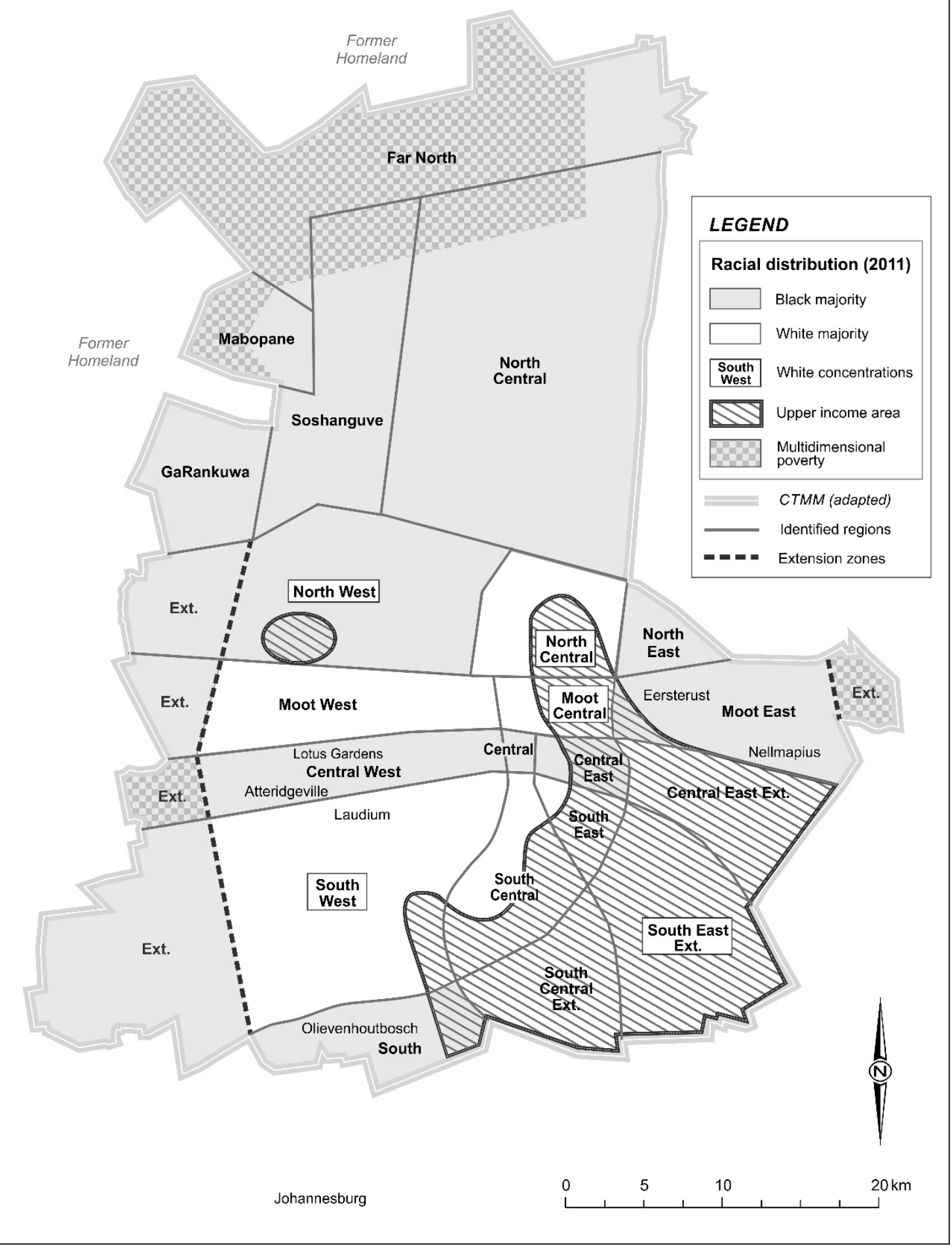

Source: the author, interpretation based on data from StatsSA 
Figure 4. Central East - desegregated and resegregated (from white to black)

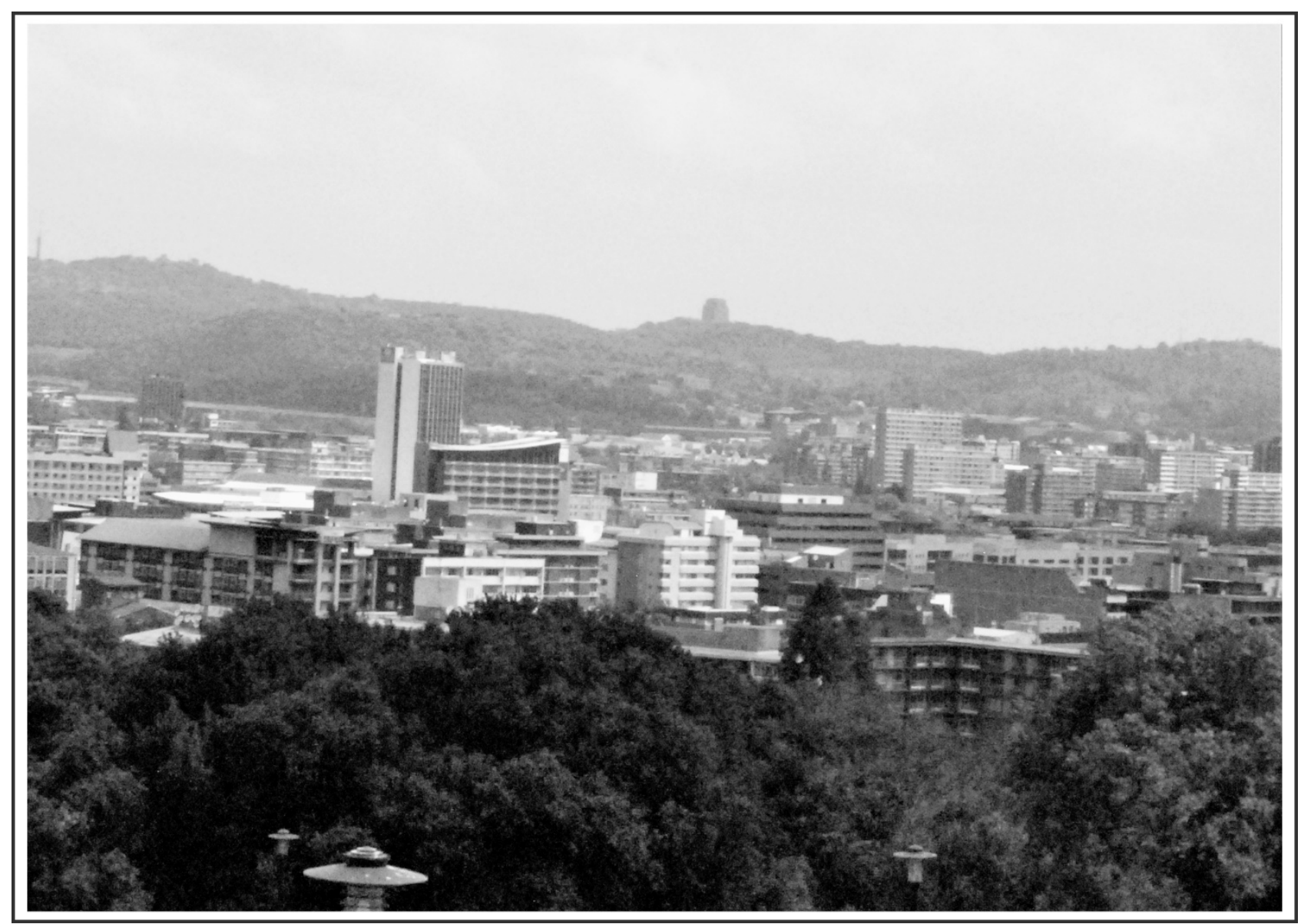

Photo: the author (2020, September 30)

Attention now shifts towards residential income distribution patterns (Table 1). South Africa is, in terms of income, one of the most unequal countries in the world with a Gini coefficient above 0,6 (Tregenna \& Tsela, 2012). Although income inequality in South Africa is to a large extent the result of apartheid's history of discrimination and exclusion (Ulriksen, 2012) the tragedy is that inequality and poverty in the country is increasing in the post-apartheid era (Katumba et. al, 2019). The national economy is wavering, the unemployment figure is above $30 \%$, and approximately 17 million people from a population of about 60 million survive on occasional work and government grants. 
Table 1. Median monthly income classification of regions

in Pretoria-Tshwane and percentage of blacks in regions (2011)

\begin{tabular}{|c|c|c|c|c|c|}
\hline URBAN REGIONS & $M-2$ & $M-1$ & M & $M+1$ & $M+2$ \\
\hline Income categories & $\begin{array}{c}\text { R } 9601-R \\
19600\end{array}$ & $\begin{array}{r}\text { R } 19601- \\
\text { R } 38200\end{array}$ & $\begin{array}{r}\text { R } 38201- \\
\text { R } 76400\end{array}$ & $\begin{array}{r}\text { R } 76401- \\
\text { R } 153800\end{array}$ & $\begin{array}{r}\text { R } 153801- \\
\text { R } 153800 \\
\end{array}$ \\
\hline Far North & 100 & & & & \\
\hline North Central Ext & & 71 & & & \\
\hline Soshanguve & & 99 & & & \\
\hline Mabopane & & 91 & & & \\
\hline GaRankuwa & & 99 & & & \\
\hline North East & & 72 & & & \\
\hline North Central & & & & & 21 \\
\hline North West & & & & & 60 \\
\hline North West Ext & & & & 65 & \\
\hline Moot West Ext & & 61 & & & \\
\hline Moot West & & & 38 & & \\
\hline Moot Central & & & & 28 & \\
\hline Moot East & & 90 & & & \\
\hline Moot East Ext & & 99 & & & \\
\hline Central East Ext & & & & & 29 \\
\hline Central East & & & 58 & & \\
\hline Central & & & 95 & & \\
\hline Central West & & & 93 & & \\
\hline Central West Ext & & 99 & & & \\
\hline South West Ext & & 83 & & & \\
\hline South West & & & & & 66 \\
\hline South & & 32 & & & \\
\hline South Central & & & & & 41 \\
\hline South Central Ext & & & & & 30 \\
\hline South East & & & & & 33 \\
\hline South East Ext & & & & & 27 \\
\hline
\end{tabular}

Note: Monthly Household income (2011): R $14=€ 1$

Source: calculated by the author from data provided by StatsSA

Since the end of apartheid the black middle class drastically increased in number and a new politically-connected elite became established. Horn (2002) captured early changes in income trends in Pretoria with the finding that between 1991 and 1996 the median income of whites increased by $61 \%$ and that of Indian/Asians by $66 \%$ compared to the $95 \%$ of coloureds and the 132\% of Africans. This trend continued thereafter (Hamann \& Cheruiyot, 2013). Simultaneously intra-racial inequality also occurred. These trends became entrenched in the Pretoria-Tshwane city pattern (Hamann, 2014). Udjo and van Aardt (2017) reported Gini-coefficients as high as +60 in Pretoria-Tshwane. 
Two income/poverty indicators are layered over the racial distribution patterns in Figure 3. The first indicates the distribution of upper income areas based on the calculations by Hamann (2014). He calculated the median income of the city and then mapped the areas that included a median $\times 2$ household income. The second indicator is based on the calculation of Katumba et. al (2019) indicating areas of multidimensional poverty based on a selected number of socioeconomic variables. The figure shows that the largest regions of upper income and multidimensional poverty are located at opposite sides of the city, with first mentioned in the south east and the other in the northwestern homeland border towns region. At the meso-scale the original apartheid pattern of the dual city remained largely in place. The correlation between racial distribution and income distribution becomes even more obvious if the racial residential distribution in Figure 3 is compared to the information provided by Table 1. ${ }^{4}$ Figure 3 shows that only a small part of the upper-income zones is in black-majority areas. In contrast, all areas of multidimensional poverty are in black majority areas. A calculation based on the information in Table 1 shows a negative correlation (-0.72) between the percentage of blacks and income. At ground level, the situation is often more complicated by rich blacks ('black diamonds') residing in overall poor townships (Donaldson et. al, 2013) and spots of black poverty in generally white high-income areas.

If read together, the figure and the table confirm that residential household income patterns and racial residential patterns broadly correspond with each other despite the finer nuances that can be observed. It is obvious that the growth of black middle- and higher-income classes have only limited impact on the overall distribution pattern of race and income in Pretoria-Tshwane.

\section{Conclusion}

After 1994 the new post-apartheid government set out to 'transform' apartheid's cities into socially and spatially integrated compact units. The key question asked in this article is if the consolidation of apartheid's multiple-faceted model of planning and development into a singlelevel municipal planning and development system has been successful. This article reports on an investigation of the success of the post-apartheid local government of Pretroria-Tshwane in its attempt to address the socio-spatial legacy of apartheid city. Specifically, attention focused on the

4 Table 1 indicates the residential household income status of identified regions in terms of the income categories of the national census of 2011 conducted by StatsSA (www.statssa.gov.za). First, the median income of PretoriaTshwane was calculated to identify the median income category (indicated as $M$ in the table). $M+1$ and $M+2$ are then the two income categories above and $M-1$ and $M-2$ the two categories below the median income category. In each case the relevant income category is indicated by the percentage of blacks. 
consolidation and compaction of the twin-city of Pretoria-Tshwane and the effort to address racially based socio-economic duality in the core city.

It emerged that the post-apartheid local government of the twin-city of Pretoria-Tshwane failed to integrated the core city with the region's homeland border towns. Consequently, the peripheral and vulnerable population of the city remains marginalised and is increasingly becoming unsatisfied with their quality of life (South African Cities Network, 2016; Koech et. al, 2019). It is evident from city strategies and plans that the northwestern arc of homeland towns remain neglected (Peberdy et. al, 2017). The second part of the investigation that focussed on the sociospatial integration revealed large scale residential desegregation in inner-city regions that then turned into re-segregation by blacks. Apart for a reasonable scale of racial desegation that occurred in regions closer to former black townships the former pattern of race and income remains in place. It also became clear that the income distribution largely correlates with the racial distribution with the gravitation point of upper-income located in the white-dominated south east of the city and regions of multiple poverty on exactly the opposite northwestern pole. This observation mirrors the apartheid-era pattern (SACN, 2016). In addition, the poor and vulnerable continue to sprawl outwards (Mgushelo, 2018).

From the evidence presented it is deducted that attempts to integrate and compact the city of Pretoria-Tshwane failed at the two scales investigated. This finding confirms earlier concerns expressed by Serfontein and Oranje (2007). Although the effort of the local government cannot be flouted as a whole it appears to be chained by idealistic political frameworks and overextended, and often foreign, planning concepts such as 'boulevards', 'gateways', 'edge cities', 'smart growth', and 'flagship' projects (e.g. City of Tshwane, 2013, 2017, 2019).

The concept of 'developmental local government' was not only new to the country but also more complex than anticipated (Lemon, 2002). Many, if not all, local governments have been unable to meet the expectation to fully integrated South African cities (South African Cities Network, 2014). According to the South African Cities Network (2016) cities continue to be characterised by spatial fragmentation exibiting racial and social dichotomies and the exclusion of the vulnerable. The relationship between local governments and other spheres and levels of government proved to be more problematic than expected (Todes, 2006). This is particularly the case where local government's try to creatively address local challenges beyond the limits of centralised populist frameworks. 
The failure of local governments to manage the loaded concept of 'spatial transformation' under a condition of blurred intergovernmental cooperation (South African Cities Network, 2016) convinced the author that a major alteration in the structuring of planning and development at the municipal level is unavoidable. The establishment of social and territorial divided city regions was done by national governments during the apartheid era and the responsibility to undo this dichotomy should be that of the post-apartheid national government. The failure to 'transform' integrated urban and rural municipal regions by local governments in general requires a multiple level of shared planning and developmental responsibilities. This will allow local governments to focus on the social welfare of its citizens. To conclude, the post-apartheid government should refrain from a complete 'cancellation' of the past and rather learn from history (Harrison et. al, 2008). In the meantime, 'pac-man' city will continue to chow on the social fabric of PretoriaTshwane.

Acknowledgements: Gratitude is expressed to the reviewers for their constructive comments.

Authorship statement: The author declares no conflict of interest. The article is the author's own, original work and has not been published elsewhere. 


\section{References}

Baffi, S., \& Turok, I., \& Vacchiani-Marcuzzo, C. (2018). The South African Urban System. In C. Rozenblat, D. Pumain \& D. Velasquez (Eds.), Internation and transnational perspectives on urban systems (pp. 285-316). Singapore: Springer.

CDE (1998a). South Africa's discarded people: survival, adaptation, and current challenges. Report 9. Johannesburg: Centre for Development and Enterprise.

CDE (1998b). Pretoria: from apartheid's model city to a rising African star? Big City Series 8. Johannesburg: Centre for Development and Enterprise.

Christopher, A. J. (1983). From Flint to Soweto: refelections on the colonial origins of the apartheid city. Area, 15(2), 145-149.

Christopher, A. J. (2001). Urban segregation on postapartheid South Africa. Urban Studies, 38(3), 449-456.

City of Tshwane (2019). Tshwane vision 2055 - remaking South Africa's capital. Pretoria: CTMM.

City of Tshwane (2017). Tshwane vision 2030 - Tshwane: a prosperous capital city through fairness, freedom and opportunity. Presentation to Select Committee on Finance, Parliament of the Repubic of South Africa, 2 August 2017.

City of Tshwane (2013). Draft revised Integrated Development Plan 2017/21. Pretoria: CTMM.

Davies, J. (1981). The spatial formation of the South African city. GeoJournal, Supplementary Issue, 2, 59-72.

Donaldson, R., Bähtr, J., \& Jürgens, U. (2002). Assessing inner city change in Pretoria, Acta Academica, 3(1), 1-33.

Donaldson, R., Mehlomakhulu, T., Darkey, D., Dyssel, M., \& Siyongwana, P. (2013). Relocation: To be or not to be a black diamond in a South African township? Habitat International, 39, 114118.

Hattingh, P. S., \& Horn, A. C. (1991). Pretoria. In A. Lemon (Ed.), Homes apart: South Africa's segregated cities (pp. 146-161). London: Paul Chapman.

Hamann, C. (2014). Socio-spatial change in the post-apartheid City of Tshwane Metropolitan Municipality (Unpublished) (MA dissertation, University of South Africa, South Africa). 
Hamann, C., \& Cheruiyot, K. (2017). Differentiating household income growth in Gauteng 20012011. GCRO Map of the Month, 31 October 2017. Johannesburg: Gauteng City Region Observatory. Retrieved from http://www.gcro.ac.za/outputs/map-of-themonth/detail/differentiating-household-income-growth-in-gauteng-2001-2011/

Hamann, C., \& Horn, A. C. (2014). Centextualising two decades of of socio-spatial change in South African urban areas. In L. Mierzejewska \& J. Parysek (Eds.), Cities in a complex world: problems, challenges and Prospects (pp. 53-62). Poznań: Bogucki Wydawnictwo Naukowe.

Hamann, C., \& Horn, AC. (2015). Continuity or discontinuity? Evaluating the changing sociospatial structure of the City of Tshwane, South Africa. Urban Forum, 26(1), 39-57.

Harrison, P., \& Todes, A. (3013). Spatial considerations in the development of urban policy in South Africa: a research paper as input into the preparation of the Integrated Urban Development Framework (IUDF). Pretoria: Department of Cooperative Development and Traditional Affairs.

Harrison, P., Todes, A., \& Watson, V. (2008). Planning and transformation: learning from the post-apartheid experience. Abdingdo: Routledge.

Horn, A. J. (2009). The life and death of urban growth management in the Gauteng province (Unpublished MTRP dissertation, University of Pretoria, South Africa).

Horn, A. C. (1998). Tshwane, Pretoria, Phelindaba: structure-agency interaction and the transformation of a South African region up to 1994, with prospects with the immediate future (Unpublished DPhil thesis, University of Pretoria, South Africa).

Horn, A. C. (2002). New perspectives on urban segregation and desegregation in postresolution South Africa. In I. Schnell \& W. Ostendorf (Eds.), Studies in segregation and desegregation (pp. 247-284). Burlington: Ashgate.

Horn, A. C. (2005). Measuring multi-ethnic spatial segregation in South African cities. South African Geographical Journal, 87(1), 58-72.

Horn, A. C., Hattingh, P. S., \& Vermaak, J. (1992) Winterveld: an interface settlement on the Pretoria metropolitan fringe. In DM. Smith (Ed.), The apartheid city and beyond - urbanization and social change in South Africa (pp. 113-124). London: Routledge.

Horn, A. C., \& Ngcobo, J. R. B. (2003). The suburban challenge: (de) segregation, opportunity and community in Akasia, city of Tshwane. Urban Forum, 14(4), 320-346. 
Katumba, S., Cheruiyot, K., \& Mushongera, D. 2019. Spatial change in the concentration of multidimensional poverty in Gauteng, South Africa: evidence from Quality of Life Survey Data. Social Indicators Research, 145, 95-115.

Koech, C., Katumba, S., \& Wray, C. (2019). Patterns and correlates of dissatisfaction with government performance in the Gauteng City-Region, South Africa: a comparison across three government spheres. The Review of Regional Studies, 49, 1-26.

Lemon, A. (1991). Homes apart: South Africa's segregated cities. Cape Town: David Phillip.

Lemon, A. (2002). The role of local government. In S. Parnell, E. Pieterse, M. Swilling \& D. Wooldridge (Eds.), Democratising local government - the South African experiment (pp. 18-30). Cape Town: UCT Press.

Maharaj B. (2020) South African urban planning in the Twentieth and Twenty-First centuriescontinuities between the apartheid and democratic eras? In R. Thakur, A. Dutt, S. Thakur \& G. Pomeroy (Eds.), Urban and Regional Planning and Development (pp. 101-112). Cham: Springer.

Maylam, P. (1995). Explaining the apartheid city: 20 years of South African urban historiography. Journal of Southern African Studies, 21(1), 19-38.

Mgushelo, A. (2018). Land acquisition and the growth of informal settlements in South Africa: the case of informal settlements in Mamelodi, City of Tshwane, 1994-2014 (Unpublished MA dissertation, University of Pretoria, South Africa).

Morris, A. (1994). The exclusion of Odi-Moretele and KwaNdebele from the PWV region: dynamics and implications. Johannesburg: Urban Foundation.

Olivier, J., \& Hattingh, PS. (1985). Die Suid-Afrikaanse stad as funksioneel-ruimtelike sisteem met besondere verwysing na Pretoria. In F. A. van Jaarsveld (Ed.), Verstedeliking in Suid-Afrika, (pp. 45-61). Pretoria: Universiteit van Pretoria.

Parnell, S., \& Crankshaw, O. (2013). The politics of 'race' and the transformation of the postapartheid space economy. Journal of Housing and the Built Environment, 28(4), 589-603.

Peberdy, P. H., \& Dinath, Y. (2017). Uneven spaces: core and periphery in the Gauteng cityregion. GCRO research report \# 06. Johannesburg: Gauteng City Region Observatory.

Perlman, J. M. (1992). The state and the African working class in the Pretoria-Odi area: population relocation, state management and class restructuring. Johannesburg: University of the Witwatersrand. 
Prinsloo, D., \& Cloete, C. E. (2002). Post-apartheid residential mobility patterns in two South African cities. Property Management, 20, 264-277.

Serfontein, K. J. (2006). An expounded reading on the conceptualization of Tshwane between 2000 and 2004 (Unpublished MTRP Dissertation, University of Pretoria, South Africa).

Serfontein, K., \& Oranje, M. (2007) Spatial connections and disconnections: a critique on the conceptualisation of Tshwane (2000 to 2004). Town and Regional Planning, 52, 20-31.

Smit, P. (1969). Die ontwikkeling van die bantoetuislande - probleme en vooruitsigte (Unpublished) (Paper presented at the Vereniging vir Aardrykskunde-onderwys, 8-11 July 1969, Potchestroom).

Smit, P., \& Booysen, J. J. (1981). Swart verstedeliking: prosses, patroon en strategie. Cape Town: Tafelberg.

South Africa (2004). Breaking New Ground - comprehensive plan for sustainable human settlements. Pretoria: Department of Human Settlements.

South African Cities Network (2014). Migration, mobility and urban vulnerabilities - implications for urban governance in South Africa. Johannesburg: SACN.

South African Cities Network (2016). Hidden urbanities: South Africa's displaced settlements 30 years after the abolition of influx control. Johannesburg, SACN.

Todes, A. (2006). Urban spatial policy. In U. Pillay, R. Tomlinson \& J. du Toit (Eds.), Democracy and delivery: urban policy in South Africa (pp. 50-74). Pretoria: HRSC Press.

Turok, I., \& Parnell, S. (2009). Reshaping cities, rebuilding nations: the role of national urban policies. Urban Forum, 20(2), 157-174.

Turok, I., \& Watson, V. (2002). Strategic challenges facing South Africa's cities. New Agenda South African Journal of Social and Economic Policy, 8, 108-119.

Tregenna, F., \& Tsela, M. (2012): Inequality in South Africa: the distribution of income, expenditure and earnings. Development Southern Africa, 29(1), 35-61.

Udjo, E. O., \& van Aardt, C. J. (2017). Linking population dynamics to municipal revenue allocation in City of Tshwane. Study commissioned by South African Cities Network. Pretoria: Bureau of Market Research (University of South Africa).

Ulriksen, M. S. (2012). How social security policies and economic transformation affect poverty and inequality: lessons for South Africa. Development Southern Africa, 29(1), 3-18. 
Van Niekerk, B. (2018). Housing as urbanism: a policy to discourage urban sprawl and provide well-located and affordable housing in South Africa. Town and Regional Planning, 73, 68-82. 